dr hab. inż. Tadeusz Maciak, prof. $\mathrm{PB}^{1}$

mł. kpt. mgr inż. Mariusz Barański²

Przyjęty/Accepted/Принята: 20.11.2014;

Zrecenzowany/Reviewed/Рецензирована: 11.16.2015;

Opublikowany/Published/Опубликована: 31.12.2015;

\title{
Wprowadzenie do komputerowego modelowania zachowania się tłumu. Wybrane aspekty psychologii tłumu ${ }^{3}$
}

\author{
Introduction to Computer Modelling of Crowd Behaviour. Selected Aspects \\ of Crowd Psychology
}

\author{
Введение в компьютерное моделирование поведения толпы. \\ Отдельные аспекты психологии толпы
}

\begin{abstract}
ABSTRAKT
Cel: Zaprezentowanie problematyki modelowania numerycznego zachowania się zgromadzeń ludzkich na tle wybranych elementów psychologii tłumu.

Wprowadzenie: W pracy zaprezentowano różne definicje i podziały zgromadzeń ludzkich, jak również cechy charakterystyczne tłumu. Omówiono klasyczne spojrzenie na zachowanie się tłumu Le Bona, które sprowadza się do dwóch zasadniczych stwierdzeń: po pierwsze tłum stanowią masy ludzi o ujednoliconym zachowaniu, które mogą być zakwalifikowane jako aktywne, ekspresyjne w wyrażaniu swojej postawy; po drugie, że uczestnicy tłumu są podatni na spontaniczne działanie, nieraz irracjonalne, z utratą samokontroli w poczuciu pełnej anonimowości. Zwrócono uwagę na pewne osobliwe zachowania jednostek ludzkich występujące w tłumie takie jak utrata poczucia indywidualności, jedność psychiczna osób biorących udział w zbiorowości oraz instynktowny proces decyzyjny. Wskazano na pewne normy zachowań postrzegane przez uczestników zbiorowości takie jak np. wzmożone naśladownictwo. Omówiono również zjawisko paniki w tłumie wywołane obawą o zagrożenie życia, które generalnie prowadzi do pojawienia się dwóch postaw tj. podjęcia próby ucieczki z zagrożonego miejsca lub przejście w stan zobojętnienia i odrętwienia wobec niebezpieczeństwa. W kolejnej części pracy zaprezentowano współczesne rozumienie zachowania tłumu, w którym podważono szereg stereotypów występujących w koncepcji klasycznej Le Bona. Modele opisujące zachowania ludzi w tłumie oparte na nowoczesnych założeniach reprezentują w pracy Model punktu zapalnego, Model społecznej tożsamości oraz Model inicjacji - eskalacji przemocy w tłumie. Omówienie obecnego stanu wiedzy na temat psychologii tłumu było podstawą do zaprezentowania kierunków modelowania numerycznego zachowania się jednostek ludzkich w tłumie. Przedstawiono zarówno podejście bazujące na prawach fizyki, gdzie tłum jest traktowany jako fizyczny płyn cząsteczkowy, oraz modelowanie agentowe, gdzie osoby w tłumie traktuje się jako jednostki autonomiczne, aktywnie postrzegające środowisko i podejmujące decyzje według z góry zdefiniowanych reguł. Omawiając różne sposoby modelowania, zwrócono uwagę na modele, które umożliwiają symulacje ewakuacji tłumu w stanie paniki.

Metodologia: Omówienie wybranych elementów składających się na psychologię tłumu w rozumieniu klasycznym jak i współczesnym stanowiło podstawę do przedstawienia obecnie istniejących kierunków modelowania numerycznego ruchu ludzi w dużych skupiskach. Wnioski i znaczenie dla praktyki: W celu zminimalizowania ryzyka wystąpienia niebezpieczeństwa dla życia osób poruszających się w tłumie podejmowane są próby opisywania i modelowania matematycznego ruchu ludzi. Symulacje komputerowe bazujące na takich modelach umożliwiają określenie krytycznych punktów na drodze ucieczki w czasie ewakuacji i następnie ich wyeliminowanie poprzez poprawienie planów budowlanych lub zastosowanie dodatkowych zabezpieczeń w przypadku istniejących budynków. Teoria psychologii tłumu ma wpływ na rozwijającą się dziedzinę symulacji ewakuacji. Odgrywa szczególną rolę, gdyż pozwala na dostosowanie procedur i etapów ewakuacji w taki sposób, aby zminimalizować możliwość powstania paniki.
\end{abstract}

Słowa kluczowe: psychologia tłumu, matematyczne modelowanie zachowania się tłumu, ewakuacja ludności Typ artykułu: artykuł przeglądowy

Politechnika Białostocka / Bialystok University of Technology;

2 Komenda Powiatowa Państwowej Straży Pożarnej w Oławie / District Headquarters of the State Fire Service, Oława, Poland; mariusz.baranski@straz.olawa.pl;

3 Procentowy wkład merytoryczny w powstanie artykułu / Percentage contribution: T. Maciak - 85\%, M. Barański - 15\%; 


\section{A BSTRACT}

Aim: Presentation of issues associated with numerical modelling of human behaviour in context of selected elements of crowd psychology. Introduction: The article identifies a range of definitions and classification of human gatherings as well as crowd characteristics. Le Bon classic view of crowd behaviour is examined and narrowed down to two basic statements: First, a crowd is made up of a mass of people, of unified behaviour, which can be classified as active, expressive in communicating their attitudes and secondly, members of a crowd are likely to behave spontaneously, sometimes irrationally, with a loss of self control influenced by a sensation of complete anonymity. Attention was focussed on the behaviour of individuals, which occur in crowds, such as a loss of sense of individuality, psychological (mental) unity of individuals taking part in a gathering and instinctive decision making process. Certain behaviour patterns were identified with people taking part in gatherings, such as increased mimicry. Additionally, the article examined the appearance of panic in a crowd caused by anxiety about life threatening dangers, which generally lead to the emergence of two stances i.e. attempt an escape from the danger zone or enter into a state of indifference and numbness in face of danger. The subsequent part of the paper reveals current understanding of crowd behaviour, where a range of stereotypes identified in Le Bon's classic concept are challenged. Models describing crowd behaviour, based on contemporary assumptions, are revealed in work titled Flashpoint Model, Elaborated Social Identity Model and The initiation-escalation model of collective violence. The discourse dealing with current knowledge about crowd psychology provided the foundation for a focus on numerical modelling of human behaviour for individuals in a crowd. Two approaches were put forward. One based on the laws of physics, where a crowd is treated as physical molecular liquid and agent-based modelling, where individuals in a crowd are treated as an autonomous entity actively perceiving the environment and making decisions according to predefined rules. The discourse involving different modelling approaches focussed attention on processes, which facilitate evacuation simulations involving crowds in a state of panic.

Methodology: Examination of selected aspects of crowd psychology in context of classical and contemporary perspectives provided a foundation for the presentation of current numerical modelling approaches dealing with the behaviour of people in large crowd gatherings. Conclusions and relevance to practice: In order to minimize the risk of danger to the life of people moving in a crowd, an attempt was made to illustrate a mathematical model dealing with the movement of people. Computer simulations based on such models facilitate the identification of critical stages along an escape route during an evacuation and their subsequent elimination through improvements to building plans, or by application of additional safety measures to existing buildings. The theory of crowd psychology has an impact on the development of evacuation simulations. It plays an important role, because it allows for the adaptation of procedures and stages of an evacuation in such a way so as to minimize the possibility of panic.

Keywords: crowd psychology, mathematical modelling of crowd behaviour, evacuation of people Type of article: review article

\section{АННОТАЦИЯ}

Цель: Представить проблематику численного моделирования поведения скоплений людей в контексте отдельных аспектов психологии толпы.

Введение: В статье представлены разные определения и классификации скоплений людей, а также характеристические черты толпы.

Рассмотрен классический взгляд на поведение толпы Лебона, который сводится к двум основным утверждениям: во-первых, толпу составляют массы людей с одинаковым поведением, которых можно класифицировать как активных, экспрессивных в выражении своего мнения; во-вторых, что люди, находящиеся в толпе, восприимчивы к спонтаническому поведению, иногда иррациональны, теряют самоконтроль из-за чувства полной анонимности. Внимание было обращено на некие нетипичные поведения человека в толпе такие как: потеря чувства индивидуальности, психическое единство людей, участвующих в коллективе, а также инстинктивный процесс принятия решений. Были указаны некоторые формы поведений участников толпы такие как, например, чрезмерное подражание. Рассмотрен также феномен паники в толпе, вызванный страхом угрозы жизни, который в общем приводит к двум типам поведения т.е. попытки бегства из опасного места или перехода в состояние безразличия и остолбенения при появлении опасности. В следующей части статьи было описано современное представление о поведению толпы, которое ставит под сомнение ряд стереотипов, присутствующих в классической концепции Лебона. Обсуждение текущего состояния знаний о психологии толпы стало основой для представления направлений численного моделирования поведения человеческих единиц в толпе.

Представлен также подход, основанный на законах физики и агентном моделировании. Обсуждая различные способы моделирования, обращено внимание на модели, которые позволяют проводить симуляцию эвакуации толпы в состоянии паники. Методология: Обсуждение отдельных элементов психологии толпы в класичесском и современном значении было основой для представления имеющихся сегодня направлений численного моделирования движения людей в больших группах.

Выводы и значение для практики: С целью минимизации риска опасности для жизни людей, которые находятся в толпе, проводятся попытки описать и математически смоделировать движение людей. Компьютерные симуляции, базирующие на таких моделях, позволяют определить критические пункты на дороге во время эвакуации и в дальнейшем их устранить, благодаря улучшению планов постройки или использованию дополнительных элементов защиты, в случае уже построенных зданий. Теория психологии толпы влияет на развивающуюся область симуляции эвакуации. Она играет особенную роль, так как позволяет адаптировать процедуры и фазы эвакуации таким образом, чтобы минимизовать возможность возникновения паники.

Ключевые слова: психология толпы, математическое моделирование поведения толпы, эвакуация людей

Вид статьи: обзорная статья 


\section{Wstęp}

Psychologia tłumu jako nowa dyscyplina nauki narodziła się w XIX wieku. Jej podłożem były przemiany społeczne zachodzące pod koniec XIX wieku w dużych miastach Europy zachodniej takich jak Paryż czy Mediolan, określane w literaturze światowej jako nowoczesna kultura miejska (modern urban culture). Jednocześnie pojawiły się nowe zjawiska kryminalne kojarzone $\mathrm{z}$ występowaniem tłumu. Pierwsza debata nad psychologią tłumu prowadzona pod kątem występowania zjawisk kryminalnych w zbiorowiskach ludzkich miała miejsce w Rzymie w roku 1885. Pierwsza publikacja na temat tłumu pojawiła się w roku 1841 (Ch. MacKay Extraordinary Delusions and the Madness of Crowds) [1]. Praca Hippolyte Taine The Origins of Contemporary France (1875) rzuciła nowe światło na rolę tłumu w rewolucji francuskiej z roku 1789 . Opisy postaw ludzkich występujące we wczesnych publikacjach zostały rozwinięte przez lekarza, antropologa i socjologa Gustava Le Bona w wydanej w 1895 roku książce Psychologie des Foules. Le Bon opisał zjawisko odmiennego zachowania się ludzi, gdy są badani pojedynczo i innego, gdy są badani w masie ludzkiej. Jest on również autorem pojęcia „tłum psychologiczny”, który określa również jako „zbiorową istotę". Zauważył, że przy zbiegu pewnych okoliczności i tylko w tych okolicznościach, zbiorowość ludzi nabiera zupełnie nowych właściwości, różnych od tych, jakie posiadają poszczególne jednostki, składające się w danym wypadku na tłum [2].

W ostatnich latach pojawily się liczne prace, w których podjęta została próba modelowania w sposób matematyczny zachowania się tłumu w różnych sytuacjach ekstremalnych $\mathrm{np}$. ewakuacji w stanie paniki. Umiejętność modelowania procesu ewakuacji tłumu z określonych obiektów pozwala wykryć miejsca, w których może dochodzić do blokowania przejść i na etapie projektu zaplanować właściwą przepustowość dróg ewakuacyjnych. Aby zrozumieć i określić prawidłowo założenia opracowanych modeli matematycznych, niezbędna jest podstawowa wiedza na temat tłumu i zachowania się jednostki ludzkiej w tłumie.

$\mathrm{W}$ artykule zaprezentowano różne definicje i klasyfikacje tłumu, jak również opisano cechy charakterystyczne zgromadzeń ludzkich. Omówiono tradycyjne, jak i współczesne rozumienie zachowania tłumu. Klasyczne spojrzenie na zachowanie tłumu przedstawiono w postaci siedmiu założeń tradycyjnych Le Bona. Modele opisujące zachowania ludzi w tłumie oparte na nowoczesnych założeniach reprezentują w pracy model punktu zapalnego, model społecznej tożsamości oraz model inicjacji - eskalacji przemocy $\mathrm{w}$ tłumie. W podsumowaniu spojrzenia psychologicznego zaprezentowano krótko obecnie istniejące kierunki numerycznego modelowania zachowania się tłumu.

\section{Kategorie zbiorowości}

Wśród różnych form zbiorowości ludzkiej znajdujących się w tym samym miejscu i w tym samym czasie można wyróżnić trzy podstawowe kategorie: zbiegowisko, publiczne zebranie oraz tłum [2]. Dwie pierwsze postacie zbiorowości mogą w pewnych warunkach przekształcić się w tłum, choć ich pierwotna przyczyna ma nieco inny charakter.

\subsection{Zbiegowisko}

Zbiegowisko jest przelotnym zgrupowaniem osób wykazujących zainteresowanie tym samym zdarzeniem. $Z$ reguły zdarzenie to jest nagłe i nieoczekiwane. Na przykład zbiegowisko ludzi wywołuje nagły wypadek drogowy, awantura na ulicy, czy też handlarz sprzedający atrakcyjny towar. Osoby w zbiegowisku starają się uzyskać informację na temat zaistniałej sytuacji. W zbiegowisku, dzięki bliskości przestrzennej, występują zbliżone reakcje emocjonalne. Nagłe zachowania jednostek mogą przekształcić się w aktywność całego zgromadzenia. Stąd też zbiegowiska zawsze muszą być brane pod uwagę jako potencjalne zagrożenie dla porządku publicznego [4].

\subsection{Publiczność zebrana}

Publicznością zebraną (audytorium) nazywamy zgromadzenie intencjonalne takie jak np. publiczność szukająca szeroko pojętej rozrywki (zgromadzenie np. w kinie, na sali koncertowej czy na zawodach sportowych). Do tej kategorii zalicza się również wiernych zgromadzonych w świątyniach oraz osoby poszukujące informacji na zebraniach informacyjnych, pokazach, czy wiecach politycznych.

Publiczność zebraną odróżnia od zbiegowiska postawa uczestników, którzy są bardziej uporządkowani w działaniu. Podobnie jak to ma miejsce w przypadku zbiegowiska, publiczność zebrana wykazuje podobne działanie. Słuchanie przemówień politycznych lub religijnych może powodować silne napięcia emocjonalne.

\subsection{Tłum}

Tłum jest formą zbiorowości, w której zjawiska zachodzące w zbiegowisku, czy w audytorium pod wpływem bardzo silnego pobudzenia emocjonalnego powodują, że wszystkie jednostki wykazują to samo zachowanie oraz jednakowy stan psychiczny. Jednostki w tłumie zawsze przebywają w bliskości fizycznej, podlegają wspólnym oddziaływaniom i mają wspólny obiekt zainteresowania. Nierozróżnialność jednostek w tłumie powoduje, że zwykłe mechanizmy kontroli społecznej tracą swoją skuteczność, a do głosu dochodzą zachowania instynktowne. Tłum jest zdolny do nieprzewidywalnych zachowań spontanicznych, a jego uczestnicy podejmują działania często chaotyczne, do których nie dopuściliby się w normalnych warunkach.

\section{Tłum - definicje, klasyfikacja i cechy charakterystyczne}

W przypadku tłumu brak jest jednolitej i ogólnie przyjętej klasyfikacji. Trudności związane z jednolitą klasyfikacją wynikają z dużej różnorodności czynników, które mogą doprowadzić do powstania tłumu. W literaturze przedmiotu można spotkać się z różnymi podziałami wynikającymi z odmiennego zrozumienia pojęcia zjawiska zbiorowości ludzkiej. Poniżej przedstawiono wybrane propozycje klasyfikacji tłumu według Le Bona, Blumera, Zajdela oraz Forsytha, które mogą być przydatne w zrozumieniu założeń matematycznych modelowania zachowania jednostek ludzkich w tłumie. 
Zgodnie $\mathrm{z}$ podziałem wprowadzonym przez Le Bona tłumy dzieli się na dwie grupy [2]:

1. Tłumy heterogeniczne:

a) bezimienne (tłum uliczny),

b) nie anonimowe (parlament).

2. Tłumy homogeniczne:

a) sekty (organizacja religijna),

b) kasty (wojsko),

c) warstwy społeczne (mieszczaństwo).

Dwie wymienione powyżej grupy różnią się tym, że pierwsza nie ma żadnego poczucia odpowiedzialności, druga zaś posiada poczucie silnie rozwiniętej odpowiedzialności, co nadaje określony kierunek ich działaniu.

Z kolei Blumer wyróżnia następujące rodzaje tłumów [3]:

1. Tłum przypadkowy, charakteryzujący się słabą interakcją pomiędzy uczestnikami lub wręcz jej brakiem. Są to jednostki, które przyciągnęło jakieś (często przypadkowe) wydarzenie. Przykładem takiego tłumu są osoby przyglądające się wypadkom, czy też osoby zgromadzone wokół stoiska w hipermarkecie.

2. Tłum konwencjonalny to jednostki zebrane w jakimś celu, który to cel jest jednak osiągany przez każdą z nich z osobna. Przykładem takiego tłumu są pasażerowie na przystanku lub widzowie w kinie. Tłum konwencjonalny czasem nazywany jest publicznością. Publiczność charakteryzuje to, że zdania na temat osiąganego celu mogą być różne.

3. Tłum ekspresyjny to taki, w którym szczególną rolę ma jakiś ładunek emocjonalny i na nim oparta jest interakcja. Przykładem takiego tłumu są uczestnicy karnawału w Rio de Janeiro.

4. Tłum aktywny jest nastawiony na działalność niszczycielską, której celem jest rozładowanie emocji lub zniszczenie jakiegoś zła czy przeciwnika. Przykładem takiego tłumu są agresywni kibice na meczach piłkarskich.

Bardziej szczegółowy jest podział wprowadzony przez

Zajdela [4]. Wyodrębnił on cztery najważniejsze kategorie:

1. Tłum agresywny atakuje jednostkę, inną zbiorowość lub instytucję. Występuje on w trzech formach, jako:

a) tłum linczujący - powstaje w wyniku wykrycia jakiegoś haniebnego faktu,

b) tłum terroryzujący - powstaje na podłożu ideologicznym, celem ataków są najczęściej mniejszości narodowe, religijne, seksualne lub inne

c) tłum walczący - formuje się w czasie zaburzeń społecznych, skierowany jest przeciwko siłom porządkowym. Od występowania takich tłumów zaczynały się zazwyczaj rewolucje i przewroty społeczne (Majdan, Kijów 2014). Techniki wywoływania tłumów walczących stanowią obiekt zainteresowania rządów i grup planujących przejęcie władzy politycznej.

2. Tłum uciekający (ogarnięty paniką):

a) niesformalizowany jak np. tłum ogarnięty paniką po wybuchu bomby, bez racjonalnego rozeznania rzucający się do ucieczki,

b) sformalizowany jak np. formalna grupa o uporządkowanym charakterze, posiadająca określony cel oraz świadoma niebezpieczeństwa. Panika powstaje wówczas, gdy grupa ta napotka coś, co spowoduje rozpad formalnych więzi. Przykładem mogą tu być oddziały wojska.

3. Tłum nabywajacy (rabujący, grabiący). Ten rodzaj tłumu występuje tylko w specyficznych sytuacjach katastrof, klęsk żywiołowych i ogólnej dezorganizacji społecznej. Tworzą się wówczas zbiegowiska, które atakują i rabują sklepy, banki, mieszkania i ludzi.

4. Tłum demonstrujący (ekspresywny). Przykładem może być tutaj tłum powstający aby dać wyraz uczuciom wdzięczności, uznania bądź potępienia lub protestu.

Jednym $\mathrm{z}$ najpopularniejszych podziałów tłumu jest klasyfikacja wprowadzoną przez Forsytha [5]. Zakłada ona podział na dwie główne kategorie - zgromadzenie i tłum (wraz z szeregiem podkategorii):

1. Zgromadzenie:

a) tłumy przypadkowe,

b) publiczność zebrana,

c) tłumy kolejkowe.

2. Tłum:
a) tłum agresywny,
- tłum linczujący,
- tłum walczący (zbuntowany).
b) tłum spanikowany:
- tłum uciekający,
- tłum zdobywający (rabujący).

Wymienione w powyższej klasyfikacji kategorie zostały już wcześniej dokładniej omówione.

\section{Klasyczne spojrzenie na zachowanie tłumu}

Klasyczna teoria psychologii tłumu, której początek dał Le Bon sprowadza się do dwóch zasadniczych stwierdzeń:

a) tłum stanowią masy ludzi o ujednoliconym zachowaniu, które mogą być zakwalifikowane jako aktywne, ekspresyjne w wyrażaniu swojej postawy i momentami wrogie,

b) uczestnicy tłumu są podatni na spontaniczne działanie, nieraz irracjonalne, $\mathrm{z}$ utratą samokontroli w poczuciu pełnej anonimowości.

\subsection{Homogenizacja struktury}

Podstawę tworzenia się tłumu stanowi proces ujednolicania zachowania jednostek ludzkich. O tym czy mamy już do czynienia z tłumem, decydują zjawiska okresowego zaniku cech indywidualnych i zmiany w psychice osób biorących udział w zbiorowości. Proces ten powoduje powstanie pewnej jedności umysłowej u jednostek biorących udział w zbiorowości, co w dalszej kolejności powoduje pojawienie się osobliwych zachowań, nietypowych dla pojedynczego osobnika. Mamy tu zanik własnych myśli i uczuć. Nosi to miano dezindywidualizacji.

\subsection{Jedność psychiczna}

W wyniku ujednolicenia zachowania jednostek ludzkich w tłumie, jego uczestnicy zaczynają czuć się anonimowo. Są w środowisku, które zapewnia im poczucie bezpieczeństwa. Dzięki temu pomiędzy jednostkami a tłumem nawiązuje się specyficzna więź emocjonalna. W tłumie występuje najdalej posunięte poczucie identyfikacji jednostek ze 
zbiorowością. Jednostki uczestniczące w tłumie z reguły przeżywają głębokie zadowolenie $\mathrm{z}$ uczestnictwa w zbiorowości działającej tak samo jak oni. Potwierdza to tezę, że tłum jest formą życia zbiorowego zaspakajającą istotne potrzeby ludzkiej natury [6]. Na tym poziomie zespolenia jednostki trzymają się razem, chcąc uniknąć izolowania. W przypadku rozerwania tłumu dążą do jak najszybszego dołączenia do innych osób. Z powyższego wynika, że jednostki zaczynają zachowywać się jak jeden zespolony organizm. Takiemu zespolonemu i ujednoliconemu organizmowi psychologowie przypisują tzw. duszę [2]. Dusza tłumu w tym przypadku stanowi element ściśle grupujący jednostki i sprawia, że tłum działa autonomicznie. Tłum potrafi obrać sobie cel działania i wszystkie jednostki dążą do realizacji obranego celu. Silna więź emocjonalna, anonimowość oraz bezpieczeństwo powodują to, że jednostki w tłumie utrzymują spójność grupy, są odważne i konsekwentne w działaniu oraz nabierają poczucia ważnej misji do spełnienia. Dotyczy to szczególnie tłumu agresywnego.

\subsection{Instynktowny proces decyzyjny}

Odpowiedź tłumu na bodziec jest nieraz bardzo gwałtowna i zacięta, a podejmowanie decyzji odbywa się na poziomie instynktu. Taki sposób podejmowania decyzji wynika z pośpiesznego interpretowania zjawisk, ponieważ w obszarze tłumu wymuszona jest konieczność szybkiego podejmowania decyzji. Sposób zachowania jest oparty na pierwotnym wrażeniu. Proces decyzyjny podejmowany jest szybko i odbywa się na poziomie podświadomości. W podświadomości zapamiętywane są wyuczone wzorce postępowania $\mathrm{w}$ danych okolicznościach. Instynktowny charakter stanowi również o tym, że tłum nie ma zdolności do nabywania i wykorzystywania doświadczenia. Co również jest ważne, nie potrafi ocenić krytycznie wydarzeń i powstrzymać się od podjęcia działania, które przyniosło mu już raz szkodę.

W kwestii postrzegania zjawisk ważną rolę odgrywa symbolika zjawisk. Symbolika upraszcza percepcję emocjonalną postrzeganych zjawisk i pozwala na nadawanie elementom otoczenia pewnych określonych znaczeń. Mogą to być znaczenia zarówno pozytywne, jak i negatywne. Przykładem pozytywnego symbolu może być oznakowanie drogi i wyjścia ewakuacyjnego, którym tłum chce się wydostać z zagrożonego obiektu. Negatywnym bodźcem będzie rozpoznanie domniemanego sprawcy wypadku, który może stać się obiektem ataku tłumu. Należy podkreślić, że symbole są dla uczestników tłumu bardzo czytelne i w istotny sposób wpływają na działanie tłumu.

Emocje, instynkt oraz anonimowość decydują o podejmowaniu działania w tłumie przez jednostki. Działanie to ma często charakter spontaniczny i w większości dość prymitywny. Przejawiający się w tłumie prymitywny sposób działania zazwyczaj nie występuje w codziennym życiu. Uwalnianie prymitywnych zachowań w życiu codziennym jest moderowane przez uznane normy zachowania. Tłum nie jest w stanie podejmować działań wymagających zaawansowanych procesów myślowych, a reakcje kierowane są przede wszystkim impulsami emocjonalnymi. Często też uczestnicy tłumu czują się silniejsi i tracą zdolność obiektywnej oceny sytuacji. Warto jednocześnie podkreślić, że tłum dając poszczególnym jednostkom poczucie siły i odwagi, pomniejsza jednocześnie odpowiedzialność, która zostaje rozdzielona na wszystkie jednostki biorące udział w zgromadzeniu.

\subsection{Elementy organizacji tłumu}

W ogólności w tłumie nie występują z góry określone normy zachowań przestrzegane przez uczestników zbiorowości. W tym sensie nie można mówić o występowaniu elementów organizacji tłumu. Niemniej istnieją zjawiska, które mogą świadczyć o pewnym chociażby okresowym uporządkowaniu działań jednostek ludzkich. Jednym z takich przykładowych zachowań jest wzmożone naśladownictwo określane jako zjawisko osmozy psychologicznej. Osmozę psychologiczną definiuje się jako zjawisko zarażania się emocjami (wchłaniania emocji innych ludzi) [7]. Polega ono na wytworzeniu u wszystkich jednostek identycznych lub podobnych stanów napięcia, powstającego na podłożu podobnego zaangażowania emocjonalnego [6]. Wystarczy by jedna osoba rzuciła chwytliwe hasło, a reszta uczestników podejmuje je w naturalny sposób. Za taki naśladowczy sposób postępowania odpowiadają tzw. neurony lustrzane [8]. Niemniej pojedynczy impuls naśladowczy podtrzymywany jest zazwyczaj przez krótki okres. W przypadku skandowania hasła po chwilowym zaangażowaniu całego tłumu, liczba osób wykrzykujących hasło silnie maleje.

Przebieg zjawiska zarażenia emocjonalnego nie jest do końca poznany. Biorą w nim udział złożone procesy, wśród których można wyodrębnić: wzmożone uleganie sugestiom, jednorodność doświadczeń w obrębie grupy, efekt zamkniętych kręgów wzrastającego podniecenia (osoba A przekazuje werbalnie emocje osobie $\mathrm{B}$, ta osobie $\mathrm{C}$, osoba $\mathrm{C}$ osobie A, a w każdym przekazie ładunek emocjonalny rośnie - tworzy się dodatnie sprzężenie zwrotne zwiększające siłę emocji w kręgu osób przekazujących sobie informacje). Oczywiście nie wszystkie informacje zarażają tłum w podobny sposób. Przekaz pozytywny z reguły odbierany jest sceptycznie i powoli. Natomiast przekaz negatywny potrafi rozchodzić się niemal błyskawicznie, doprowadzając często tłum do paniki. Próby uspokojenia spanikowanego tłumu niestety z reguły kończą się niepowodzeniem. Natomiast o wiele łatwiej jest, przekazując informacje o zagrożeniu, tłum usposobiony w sposób pozytywny zamienić na tłum spanikowany.

Zjawisko naśladownictwa ma swoje zauważalne konsekwencje. Tworzy dogodne warunki do rozprzestrzeniania się fałszywych spostrzeżeń i sugestii.

\section{Zjawisko paniki w tłumie}

Zdarza się, że w tłumach może dochodzić pod wpływem pewnych bodźców zewnętrznych lub na wskutek wewnętrznych interakcji do zjawiska poczucia przez jednostki ekstremalnej obawy o swoje życie. Pojawiają się wówczas w tłumie zachowania nie do końca przewidywalne, służące obronie zagrożonego życia. Takie zachowania noszą nazwę paniki. Pojawiające się zagrożenie często nie jest na tyle duże, aby w rzeczywistości zagrozić życiu ludzi. 
Niemniej występujący lęk potęguje przerażenie i wzmaga działania obronne. Stąd też panika pojawia się często bez rzeczywistych powodów mogących zagrozić życiu jednostek znajdujących się w tłumie. Panice towarzyszą zmiany wegetatywne, przymglenie świadomości (obniżona kontrola postępowania) oraz zerwanie więzi społecznych [9].

\subsection{Zmiany wegetatywne}

Obawa o życie powoduje w organizmie człowieka szereg procesów fizjologicznych powodujących początkowo niewielkie, a następnie znaczne otwarcie kanałów naczyniowych w błonie włókien nerwowych umożliwiających dodatkowy przepływ jonów sodu [10]. Obecność zwiększonego stężenia jonów sodu prowadzi do nietypowych reakcji organizmu. Proces postrzegania rzeczywistości przez jednostkę staje się w tym momencie zaburzony i nienaturalny.

Jednocześnie następują zmiany w funkcjonowaniu organizmu, które mają przygotować organizm do działania z maksymalną sprawnością. Następuje przyspieszenie bicia serca oraz przyspieszanie akcji oddychania, aby dostarczyć więcej tlenu do organów potrzebnych do sprawnej ucieczki. Organizm wtłacza więcej krwi do kończyn, a wycofuje krew z miejsc mniej ważnych takich jak np. żołądek.

\subsection{Zachowanie ludzi ogarniętych paniką}

Osoba ogarnięta paniką ma poczucie zbliżającej się katastrofy. Taki stan świadomości człowieka ogarniętego lękiem o swoje życie prowadzi do pojawienia się generalnie dwóch postaw. Pierwsza postawa polega na podjęciu próby ucieczki z zagrożonego miejsca bez zwracania uwagi na otoczenie. Druga postawa (rzadziej spotykana) to przejście osoby spanikowanej w stan zobojętnienia wobec niebezpieczeństwa i odrętwienie.

\subsubsection{Ucieczka z zagrożonego miejsca}

W momencie podjęcia decyzji ucieczki z zagrożonego miejsca, najważniejsze staje się indywidualne przetrwanie. Ludzie ogarnięci paniką stają się niewrażliwi na elementy otoczenia, które są nieistotne z punktu widzenia indywidualnego przetrwania. W tłumie dochodzi do głosu tylko indywidualny instynkt samozachowawczy. Poczucie spójności z innymi osobami zanika. W panice zanikają więzi emocjonalne także z osobami bliskimi. To oznacza faktyczny zanik wszelkich więzi społecznych. W ucieczce dominuje strach, niekontrolowany żadną refleksją. Druga jednostka przestaje istnieć, zostaje zredukowana do postaci fizycznej przeszkody. Ludzie kierują się emocjami, a to prowadzi do zaburzenia procesu podejmowania logicznych decyzji i racjonalnego działania.

Człowiek w panice stosuje rozwiązania siłowe. Polega to na odpychaniu innych osób w celu utorowania sobie drogi ucieczki. Odpychane osoby popychają osoby stojące obok. W spanikowanym tłumie bardzo łatwo o upadek. Upadek jest w takiej sytuacji niezwykle niebezpieczny. Osoba, która upadnie, w panującym ścisku uciekającego tłumu nie jest w stanie się podnieść i jest narażona na śmiertelne stratowanie przez uciekający tłum, który nie jest nawet świadomy, że na ziemi znajdują się przewrócone osoby. Jak wspomniano, w spanikowanym tłumie ludzie zauważają tylko swój indywidualny interes. Bywa, że potrafią odciągnąć innych od wyjścia, licząc że dzięki temu sami łatwiej wydostaną się na zewnątrz. Często również w spanikowanym tłumie zagęszczenie przeciskających się przez wyjścia ewakuacyjne ludzi jest tak duże, że dochodzi do zablokowania się drogi ucieczki. Oddziaływanie pomiędzy spanikowanymi osobami nawzajem, pomiędzy osobami a ścianami $\mathrm{i}$ innymi elementami architektonicznymi budynku powoduje powstawanie w środowisku tłumu wielkich ciśnień o wartościach przekraczających $4,5 \mathrm{kPa}$. W warunkach tak wysokiego ciśnienia wyginają się metalowe poręcze, a nawet pękają słabsze ścianki działowe. Ciśnienie może doprowadzić do urazów ciała lub w skrajnych przypadkach do uduszenia słabszych fizycznie jednostek [11].

Niezwykle stresowa sytuacja uniemożliwia logiczne rozpoznanie sytuacji. Często dochodzi do bezmyślnego podążania za całą uciekającą grupą, zamiast poszukiwania drogi ewakuacji na własną rękę. Znane są przypadki tratowania się osób pod jednym z wyjść, gdy przez inne można wyjść bezpiecznie.

\subsubsection{Postawa zobojętnienia}

Podczas analizy zachowania osób w tłumie ogarniętym paniką, należy również wspomnieć o innej formie panicznego lęku. U niektórych osób stan paniki przybiera formę przejścia $\mathrm{w}$ stan zobojętnienia. Jest to wynik zadziałania mechanizmu obronnego człowieka przed stresem, w którym zauważa on, że nie jest w stanie nic zrobić, aby wydostać się z zagrożonego miejsca. Towarzyszy temu poczucie bezradności, odrętwienia oraz zahamowania ruchowego. Taki stan jest również niezwykle groźny, ponieważ uniemożliwia danej osobie ucieczkę. Ponadto paraliż ruchowy stanowi poważny problem dla osób, które chcą pomóc danej osobie w ewakuacji [12].

\section{Współczesne rozumienie zachowania tłumu}

We współczesnym świecie zrozumienie zachowania tłumu jest niezwykle ważne. Badanie zachowania się tłumu nie jest jednak rzeczą prostą. Teoretyczny postęp w zrozumieniu zachowania tłumu jest utrudniony przede wszystkim ze względu na stosowaną metodologię. Do badań tłumu służą różnorodne instrumenty badawcze na przykład: studia przypadków, badanie wsteczne incydentów, wywiady i badania obserwacyjne. Badania obserwacyjne są obecnie głównym narzędziem badawczym wykorzystywanym $\mathrm{w}$ analizie zachowania się tłumu. Trudność wykonania kontrolowanych eksperymentów stanowi największe ograniczenie w rozwoju badań tłumu. Istnieją również ograniczenia etyczne - przeprowadzony eksperyment może być niebezpieczny dla osób biorących udział w doświadczeniu. Wykonywanie eksperymentów może być możliwe tylko dla mniejszych grup, które w kwestii zachowania nie powodują wysokiego poziomu ciśnienia lub przemocy. Dla większości sytuacji zachodzących w tłumie wzrost poziomu ciśnienia jest integralną częścią zjawiska. Stąd też jest prawie niemożliwe, aby wysunięte teorie przetestować doświadczalnie, a co za tym idzie, by zrozumieć i prawidłowo wyjaśnić zachowanie tłumu [13].

Jednocześnie analizując zjawiska psychologiczne zachodzące u osób będących członkami zbiorowości, należy zwrócić uwagę na to, że człowiek w sytuacji zagrożenia zachowuje się adekwatnie do posiadanych przez siebie danych [14]. 
Niekoniecznie zjawiska, które są postrzegane z zewnątrz jako panika, są podobnie odczuwane przez członka zbiorowości znajdującego się w określonym miejscu. Może to prowadzić do sytuacji, w której działania zagrożonych osób nie będą w pełni pokrywać się z zamiarami projektantów systemów oraz osób kierujących ewakuacją [15].

W roku 1968 Couch zanegował wiele stereotypów klasycznej teorii Le Bona zachowania się tłumu. Wyniki jego prac pokazują inne oblicze szeregu dotychczas uważanych za poprawne twierdzeń [16]. Według Coucha:

a) tłum nie jest jednorodną masą, ale składa się w mniejszości z pojedynczych osób oraz w większości z małych grup osób, które zapoznały się ze sobą,

b) uczestnicy tłumu nie są zgodni w motywacji, rzadko działają w harmonii, działanie harmonijne nie trwa długo,

c) tłumy nie paraliżują indywidualnego poznania, nie wyróżniają się specjalnie w przemocy oraz działaniach destabilizujących,

d) indywidualne postawy i cechy osobowości, jak również zmienne warunki społeczno-ekonomiczne, demograficzne i polityczne są słabymi wskazówkami co do indywidualnego zaangażowania w wywoływaniu i uczestnictwie w zamieszkach.

Wymienione powyżej spostrzeżenia i wykonane przez innych autorów badania pozwoliły na podważenie szeregu pewnych uznanych twierdzeń obowiązujących od czasu Le Bona:

- idea sugestywności: ludzie w tłumie chętniej naśladują innych,

- idea niszczycielstwa: jednostki w tłumie są bardziej skłonne do działania w sposób gwałtowny,

- idea spontaniczności: przemoc w tłumie występuje nagle,

- idea anonimowości: jednostki w tłumie czują się bardziej anonimowo,

- idea jednolitości: wszyscy w tłumie postępują w ten sam sposób.

W ostatnich latach w miarę analizy dostępnych dobrze udokumentowanych przypadków, sposób podejścia do modelowania tłumu podlegał dalszym głęboko idącym zmianom. W obecnej chwili dominują trzy główne sposoby podejścia do modelowania zachowania się tłumu:
a) model punktu zapalnego,
b) model społecznej tożsamości,
c) model inicjacji-eskalacji przemocy zbiorowej.

\subsection{Model punktu zapalnego}

Model punktu zapalnego (Flashpoint Model) zaproponowany przez Waddingtona i współpracowników wyjaśnia, w jakich okolicznościach może dojść do wybuchu publicznych zaburzeń [17]. „Punkty zapalne” stanowią zdarzenia, które mogą rozpętać chaos zamieszek. Analiza jest przeprowadzana w obrębie wybranych ogólnych ram strukturalnych. Ogólne ramy strukturalne integrują ze sobą istotne czynniki mogące powodować publiczne zaburzenia, przypisując je do danego poziomu analizy i wyjaśniając z każdego poziomu, na ile zainicjowanie chaosu jest prawdopodobne. Model posiada sześć współzależnych od siebie poziomów analizy: strukturalny, polityczno-ideologiczny, kulturowy, kontekstowy, sytuacyjny i interakcyjny.

Każdy poziom opisuje związek pomiędzy nieładem a istotnymi czynnikami mogącymi spowodować wybuch zamieszek. Czynniki zmieniają się od globalnych czynników kontekstowych (makro) do czynników interakcji bezpośredniej (mikro). Jeśli chodzi o poziom interakcji - brane są pod uwagę bezpośrednie interakcje pomiędzy grupami, aby wyjaśnić potencjalny chaos. Każdy poziom analizy funkcjonuje jako wskaźnik sytuacyjny, powiadamiając, czy dane zdarzenie może oddziaływać jako punkt zapalny.

Omawiany model punktu zapalnego został w kolejnych latach po jego przedstawieniu mocno skrytykowany. Głównym zarzutem w stosunku do przedstawionego modelu jest to, że nie obejmuje on fazy mobilizacji i samoorganizacji tłumu oraz roli służb porządkowych. Brak również wyjaśnienia pojawienia się zamieszek bez wyzwalającego impulsu zewnętrznego oraz mechanizmu odpowiedzialnego za opóźnioną odpowiedź na zewnętrzny impuls wyzwalający.

\subsection{Model społecznej tożsamości}

Model społecznej tożsamości (Elaborated Social Identity Model - ESIM) jest społeczno-psychologicznym modelem wyjaśniającym zachowanie tłumu, który w założeniach zawiera koncepcję jednostki postrzegającej swoje członkostwo w odpowiedniej grupie społecznej. Tłumy są połączeniem jednostek, $\mathrm{z}$ których wszystkie należą do różnych sprzecznych grup. Jednakże, jeśli tłum jest przede wszystkim związany z pewną określoną grupą (np. chrześcijan i aktywistów obrony praw obywatelskich), to wartości tej grupy będą dyktować działania tłumu. Pierwotnie teoria tożsamości społecznej (Social Identity Theory - SIT lub Social Identity Model - SIM) została sformułowana przez Henriego Tajfela i Johna Turnera w latach 1970 i 1980 [18]. Do teorii wprowadzono pojęcie tożsamości społecznej, które odgrywa kluczową rolę w analizie procesów społecznych i zachowań międzygrupowych [19]. Następnie model został rozwinięty przez Reichera, Drury'ego i Stotta i opatrzony nazwą Elaborated Social Identity Model (ESIM). Zgodnie $\mathrm{z}$ przedstawionym przez nich modelem, działania zbiorowe, tj. działania wspólne mogą mieć miejsce jedynie, gdy członkowie grupy podzielają lub postrzegają siebie jako dzielący wspólną tożsamość społeczną. Uczestnicy tłumu charakteryzują się przede wszystkim szeregiem tożsamości społecznych, które okazują się najistotniejsze w obrębie systemu psychologicznego określającego własne „ja” jednostki. Działania zbiorowe stają się możliwe, kiedy poszczególne tożsamości społeczne są jednocześnie wyraziste i podzielane przez poszczególnych uczestników tłumu.

Postrzeganie cech i norm grupowych zmienia się na przestrzeni czasu i jest traktowane jako zmiana społeczna [20].

Model ESIM bierze również pod uwagę efekt działania sił policyjnych na zachowanie się tłumów. Ostrzega, że bezzasadne użycie siły może stworzyć w tłumie na nowo poczucie jedności szczególnie w warunkach nielegalności zgromadzenia i sprzeciw wobec działania sił porządkowych. Może to spowodować wciągnięcie tłumu w konflikt z policją, pomimo postawy wahania się niektórych jednostek. 
Omawiany model jest jednym z najlepszych obecnie dostępnych modeli wyjaśniających procesy leżące u podstaw zachowania tłumu. Kładzie on silny nacisk na chaos i kontekst społeczny. Choć potwierdza on znaczenie społecznego kontekstu, rola innych czynników sytuacyjnych nie jest brana pod uwagę w znacznym stopniu. Nacisk położony jest na interakcję pomiędzy grupami. Podobnie jest w modelu punktu zapalnego. Poziom indywidualnego zachowania jednostek nie został tak naprawdę w rozpatrywanym modelu wzięty pod uwagę.

\subsection{Model inicjacji - eskalacji przemocy zbiorowej}

Model Inicjacji - eskalacji przemocy zbiorowej (The Initiation-escalation Model of Collective Violence) został zaproponowany przez Adanga [21]. Opisuje on uwarunkowania inicjacji przemocy w oparciu o systematyczne badania obserwacyjne protestów ulicznych i zamieszek piłkarskich. W swoich obserwacjach zauważa on, że przemoc nie może być rozumiana bez obserwacji oddziaływania co najmniej dwóch stron, które zawsze występują. Biorąc pod uwagę, że zachowanie tłumu stanowi trudną domenę badań empirycznych, w opracowaniu pokazuje jednocześnie, że możliwe jest przeprowadzenie użytecznych badań obserwacyjnych. Wykonane przez niego obserwacje udowodniły brak irracjonalnych zachowań ludzi w tłumie. Przeciwnie ludzie zachowują się w sposób, który ma znaczenie dla nich samych. Obserwowalny jest brak jednolitości, tzn. nie każdy działa dokładnie w taki sam sposób. Jednostki różnią się, różni ich sytuacja lokalna, a tym samym dokonują indywidualnych wyborów na podstawie tego, co wiedzą o niejednorodnym zachowaniu tłumu. Adang odnosi się również do innych spostrzeżeń odnośnie postępowania [22], [23], [24] twierdząc, że będąc w tłumie nie ma osoby bardziej brutalnej niż na zewnątrz tłumu.

Obserwacje opisują rzeczywiste zjawiska rozgrywające się w tłumie - inicjację przemocy oraz jej eskalację. Rozróżnia się dwa sposoby, w których inicjowana jest przemoc zbiorowa: przemoc, która posiada klarowną identyfikację wyzwalacza (reakcja na sytuację zewnętrzną, czyli reaktywna) z jednej oraz przemoc, która nie posiada wyzwalacza, co sprawia, że wydaje się samoistna. Ostatni rodzaj przemocy, bez jasnego czynnika wyzwalającego, występuje w zgromadzeniach niemal wyłącznie wśród osób nastoletnich lub młodych dorosłych mężczyzn.

Eskalację przemocy zbiorowej wyjaśnia się poprzez połączenie dwóch różnych mechanizmów: postrzegania ryzyka i istnienia percepcji „my kontra oni” (antagonizm) pomiędzy grupami. Postrzeganie ryzyka obejmuje mechanizm opisujący potencjalną eskalację w oparciu o postrzegane ryzyko w stosunku do możliwości. Szczególnie młodzi dorośli mężczyźni mają tendencję podejmowania większego ryzyka i zachowywania się gwałtownie. Często poszukują okazji do konfrontacji rywalizujących ze sobą grup, do czego prowadzi ich zmniejszone postrzeganie ryzyka we wspólnym działaniu w zespole z kolegami.

Model podkreśla kontekstowe podejście do zrozumienia eskalacji i prowadzi do kilku praktycznych wniosków, w szczególności, jak uniknąć starć pomiędzy grupami.
W przeciwieństwie do większości modeli, model ten wyjaśnia zachowanie antagonistycznych grup, co czyni go skutecznym w wyjaśnianiu powstania punktu zapalnego generującego przemoc w warunkach zaistnienia zewnętrznego impulsu wyzwalającego, jak również wybuchu samoistnego.

\section{Sposoby podejścia do modelowania numerycznego zachowania się tłumu}

Przedstawione w powyższych punktach modele zachowania jednostki w tłumie są niezwykle trudne do modelowania matematycznego. W zasadzie nie ma możliwości wzięcia pod uwagę wszystkich czynników, które mogą doprowadzić np. do powstania paniki w tłumie. Stąd też numeryczne podejście do zachowania się tłumu można wykonać tylko z pewnym przybliżeniem w określonych dość uproszczonych warunkach brzegowych [25].

Ogólnie istnieją dwa główne podejścia do modelowania komputerowego zachowania tłumu: makroskopowe i mikroskopowe. Pierwsze podejście bazujące na zasadach hydrodynamiki traktuje tłum jak płyn o laminarnym przepływie [26]. Inny model makroskopowy traktuje osoby w zbiorowości jak cząsteczki poddające się siłom pola magnetycznego [27]. Podejście mikroskopowe, rozwijane od pewnego czasu, polega na modelowaniu pojedynczych osób w tłumie, którym przypisuje się pewien sposób podejmowania decyzji i zachowania zgodnie z określonymi regułami. Można tu wymienić modele oparte na metodach dynamiki molekularnej, sztucznej inteligencji, niehomogenicznych automatach komórkowych oraz systemach agentowych.

\subsection{Modele makroskopowe}

W modelowaniu makroskopowym najbardziej popularne jest traktowanie tłumu jak płynu cząsteczkowego. Przez zastosowanie pewnych uproszczeń, można odnaleźć tu analogię pomiędzy zachowaniem się cząstek cieczy lub gazu a zachowaniem się jednostek ludzkich. Do opisu przepływu takiego medium wprowadza się znane $z$ mechaniki i termodynamiki równania Naviera-Stokesa [28], [29], [30]. Brane do rozważań cząsteczki odpowiadające osobnikom w tłumie nie wykazują działania charakterystycznego dla osób myślących. Stąd też modele dynamiki płynów poprawnie odzwierciedlają przepływ strumieni jednostek ludzkich. Niestety w sytuacji ekstremalnego zagrożenia tłum zaczyna zachowywać się irracjonalnie, czego podejście to nie uwzględnia. Omawiana rodzina modeli jest bardzo szeroka i jak wspomniano znajduje różnorodne zastosowania głównie w modelowaniu przepływu strumieni jednostek ludzkich.

\subsection{Modelowanie mikroskopowe}

W odróżnieniu od podejścia, które zakłada że jednostki w tłumie są bezmyślnymi fizycznymi cząsteczkami, modelowanie mikroskopowe uwzględnia osoby w tłumie jako jednostki autonomiczne, które aktywnie odczuwają środowisko i podejmują decyzje, według wstępnie zdefiniowanych reguł. Takie podejście jest również blisko związane z teorią gier, systemów złożonych i symulacji Monte Carlo [31]. 
W ostatnich latach przedstawiono wiele opracowań bazujących na modelowaniu mikroskopowym tłumu. Można wśród nich wyróżnić dwa powszechnie znane: model sił społecznych (Social-force Model) zaproponowany przez Helbinga [32-33] i cząstek samobieżnych (Self-propelled Particles - SPP) zaproponowany przez Vicseka w 1995 roku [34], [35], [36]. W praktycznych zastosowaniach obiecujące są modele z zastosowaniem niehomogenicznych automatów komórkowych oraz powiązanych systemami agentowymi.

\subsubsection{Model sił społecznych}

Model sił społecznych operuje opisami behawioralnych procesów autonomicznych osób, które postrzegają środowisko, w którym się znajdują i podejmują stosowną decyzję. Piesi są reprezentowani za pomocą cząstek dążących w określonych kierunkach, na które oddziałują siły odpychania bądź przyciągania od innych pieszych lub elementów otoczenia. W numerycznych przeliczeniach symulację tego typu wykorzystuje się do analizy przemieszczania się pieszych i ich wzajemnego oddziaływania w tłumie. Ponadto model sił społecznych może służyć do symulacji paniki tłumu.

Od opublikowania pracy Helbinga powstało szereg odmian i rozwinięć tej metody. Ponadto na bazie klasycznego modelu Helbinga powstały zupełnie nowe metody. Omawiane podejście posiada zarówno szereg zalet, jak i wad, co ogranicza zasięg stosowalności modelu. Zasadniczą wadą proponowanego rozwiązania jest mała wydajność obliczeniowa oraz trudności z odwzorowaniem złożonych scenariuszy. W przypadku symulowania dużych obiektów należy się liczyć z wysokimi nakładami obliczeniowymi.

Wiele materiałów związanych z modelowaniem można znaleźć na stronie internetowej Politechniki w Zurichu - miejscu pracy Helbinga [37].

\subsubsection{Model cząstek samobieżnych}

Model cząstek samobieżnych (Self-propelled Particles - SPP) stosuje się do badania wzajemnego oddziaływania jednostek w tłumie oraz do analizy powstawania zbiorowego ruchu tłumu.

Założenia modelu są bardzo proste. Autonomiczne cząsteczki, z których każda posiada wewnętrzną siłę napędzającą, mogą poruszać się w przestrzeni jedno, dwuwymiarowej lub trójwymiarowej. Każda cząsteczka posiada swoją strefę oddziaływania, w obrębie której reaguje na inne cząsteczki. Dokładna postać tego oddziaływania zależy od przyjętego modelu, ale ogólnie oddziaływanie to sprowadza się do odpychania, przyciągania bądź równoległego ruchu w obrębie jednej bądź wielu różnych stref. W każdym kroku czasowym, rozważane osoby koordynują swoje kierunki i prędkość poruszania się z prędkościami i kierunkami poruszania się jej najbliższych sąsiadów. Gdy poziom koordynacji jest wysoki, mamy do czynienia ze zbiorowym skoordynowanym ruchem tłumu. W modelu uwzględniono siły reakcji i tarcia. Stał się popularny, ponieważ w relatywnie prosty sposób oddaje fizyczne oddziaływanie i samoorganizację tłumu poprzez proste reguły ruchu [23], [38].

Oba przedstawione rozwiązania mają jedną wspólną wadę. Do symulacji dużych obiektów wymagane są wysokie nakłady obliczeniowe, które ograniczają zakres stosowania zaprezentowanych metod. W związku z powyższym poszukiwano innych bardziej efektywnych rozwiązań. Takimi efektywnymi rozwiązaniami stają się modele bazujące na automatach komórkowych i systemach agentowych.

\subsubsection{Modele bazujące na automatach komórkowych}

W ostatnich latach silnie rozwijane są również modele ruchu jednostek symulowane za pomocą technologii automatów komórkowych (Cellural Automata - CA). Automaty komórkowe są znanym pojęciem matematycznym służącym do modelowania szeregu zjawisk fizycznych. Popularna definicja automatu komórkowego [39] określa go jako siatkę komórek przestrzeni $D$-wymiarowej charakteryzowanej zbiorem stanów si pojedynczej komórki, zawierającej $k$-elementów. Dodatkowo specyfikuje się regułę $F$ określająca stan komórki w chwili $t+1$ w zależności od bieżącego stanu danej komórki i komórek ją otaczających w chwili $t$. Klasyczne definicje automatów komórkowych (homogenicznych) zakładają szereg założeń (np. jednorodność modelu polegająca na jednakowej definicji sąsiedztw dla wszystkich komórek), które uniemożliwiają precyzyjne modelowanie zachowania pieszych. Aby modelować ruch pieszych, należało odejść od lokalnie zdefiniowanych reguł. W ten sposób powstały modele niehomogeniczne automatów komórkowych [40]. Automat niehomogeniczny daje możliwość uwzględnienia różnych typów komórek takich jak np. przestrzeń ruchu, ściany działowe, drzwi, czy też wyodrębnienie innych przeszkód. Daje możliwość zróżnicowania funkcji przejścia pomiędzy komórkami, a także ustalenia kolejności synchronizacji stanów komórek. Ciekawym rozwiązaniem jest tzw. „rozszerzony” automat komórkowy, który umożliwia tworzenie złożonych symulacji przy wysokiej efektywności obliczeń [41].

\subsubsection{Systemy agentowe}

Systemy agentowe są reprezentacją wiedzy w dziedzinie sztucznej inteligencji. Nie istnieje jednak jedna spójna uznawana definicja agenta. Ogólnie agentem możemy nazwać oprogramowanie bądź system, który odbiera informacje z otoczenia i reaguje na nie. Agent posiada zdolność rejestrowania poprzez odpowiednie sensory środowiska, w którym przebywa, analizowania odbieranych bodźców i podejmowania samodzielnych decyzji. Agent jest autonomiczny, może podejmować samodzielne decyzje. Jest również mobilny i może zmieniać swoje położenie w środowisku. Agent może przejawiać zachowanie społeczne, czyli potrafi postrzegać inne agenty i wchodzić z nimi w interakcje (modele wieloagentowe - Multi Agent Systems - MAS). Najczęściej rozważane są grupy agentów w określonym środowisku. Agenty oraz środowisko, w którym działają tworzą system agentowy [42].

Do symulacji tłumów wyodrębniła się z modeli wieloagentowych specjalna klasa określana jako Situated Cellular Agents (SCA). W modelu SCA zapewniona jest regularna struktura przestrzeni bytowania agenta (może być i struktura nieregularna). Określone są różne sposoby interakcji pomiędzy sąsiednimi agentami: oddziaływanie synchroniczne i asynchroniczne oraz oddziaływanie na odległość przez specjalny mechanizm percepcyjny (pole potencjału agenta). Heterogeniczne agenty mogą być otrzymane przez właściwą definicję typu agenta. Definicja typu agenta 
specyfikuje różne zachowanie i wprowadza mechanizm filtrowania przychodzących informacji (określa zdolności percepcyjne) [43-44].

Interesującym rozwiązaniem jest połączenie koncepcji automatów komórkowych $\mathrm{z}$ modelami wieloagentowymi. Piesi w takich modelach reprezentowani są przez agentów, którzy mogą podejmować działania w oparciu o obserwację otoczenia oraz zachowanie innych agentów. Formalizm opisu systemów agentowych zakłada siatkę jako przestrzeń bytowania agentów. W przedstawionych modelach zakłada się również możliwość oddziaływania pomiędzy agentami. Przyjęcie takich założeń umożliwia odwzorowanie złożonych scenariuszy przepływu pieszych [45].

Należy dodać, że często modele klasyfikowane jako systemy agentowe bazują na automatach komórkowych.

\section{Podsumowanie}

Przemieszczanie się tłumów badano przez ponad trzy dekady. Jednakże badania dotyczące przepływu tłumów pieszych związanych z wydarzeniami wyjątkowymi są ograniczone w porównaniu z przepływem pieszych w normalnym środowisku spacerowym. W dużych tłumach istnieje możliwość zranienia, a nawet utraty życia, co wynika z dynamiki zachowania tłumu. Biorąc pod uwagę rosnącą liczbę dużych imprez sportowych, spotkań religijnych,

\section{Literatura}

[1] Forsyth D.R., Handbook of Psychology, second edition, 2012.

[2] Le Bon G., Psychologia tłumu, PWN, Warszawa 1986.

[3] Blumer H., Social problems as collectiva behavior, „Social Problems", Vol. 18 Issue 3, 1971, pp. 298-306 [dok. elektr.] https://sustainability.water.ca.gov/documents/18/3407898/ blumer-Social+Problems+as+Collective+Behavior.pdf, [dostęp: 09.2015].

[4] Zajdel M., Komputerowe modelowanie zachowań zbiorowości ludzkich w stanach paniki, Praca doktorska, AGH, 2013, [dok. elektr.] http://winntbg.bg.agh.edu.pl/rozprawy2/10622/full10622.pdf, [dostęp: 09.2015].

[5] Forsyth D.R., Group dynamics, Wadsworth Publishing, New York 1999.

[6] Szczepański J., Elementarne pojęcia socjologii, wyd. 3, PWN, Warszawa 1972.

[7] Le Bon G., Psychologia tłumu, Wydawnictwo Antyk, Kęty 2004.

[8] Arbib M. (red.) The mirror system hypothesis on the linkage of action and languages, [w:] Action to language via the mirror neutron system, Cambridge University Press, Cambrige 2011.

[9] Krocz K., Ataki paniki, ABC Zdrowie, 2012, [dok. elektr.], http://portal.abczdrowie.pl/atak-paniki, [dostęp 09.2015].

[10] Guyton A., Hall J., Textbook of medical physiology, 12 edition, Saunders Elsevier, Philadelphia 2011.

[11] Lee R.S.C., Hughes R. L., Prediction of human crown pressures, „Accident Analysis and Prevention”, Vol. 38 Issue 1, 2006, pp. 712-722.

[12] Kita E., (2012). Panika jak sobie z niq radzić, [dok. elektr.] http://www.edukacja.edux.pl/p-8157-panika-jak-sobie-z-nia-radzic.php, [dostęp 09.2015]. koncertów rockowych i zagrożeń pożarowych dużych budynków, kwestia bezpieczeństwa w szczególności ewakuującego się tłumu ma coraz większe znaczenie. W celu zminimalizowania ryzyka wystąpienia niebezpieczeństwa dla życia osób poruszających się w tłumie o dużym zagęszczeniu, niezbędne jest właściwe zrozumienie zjawisk występujących w takich środowiskach. Służą temu podejmowane próby opisywania i modelowania matematycznego ruchu ludzi w czasie ewakuacji. Symulacje komputerowe bazujące na takich modelach umożliwiają określenie krytycznych punktów na drodze ucieczki i następnie ich wyeliminowanie poprzez poprawienie planów budowlanych lub zastosowanie dodatkowych zabezpieczeń w przypadku istniejących budynków. Niejednokrotnie symulacje dają również możliwość określenia wymaganego czasu bezpiecznej ewakuacji oraz określenie liczby osób mogących przebywać jednocześnie w budynku lub innym obiekcie budowlanym, przy której bezpieczna ewakuacja jest możliwa [36], [47]. Teoria psychologii tłumu ma wpływ na rozwijającą się dziedzinę symulacji ewakuacji. Pozwala także na dostosowanie procedur i etapów ewakuacji w taki sposób, aby zminimalizować możliwość powstania paniki.

Artykuł został sfinansowany z pracy statutowej Wydziału Informatyki Politechniki Białostockiej S/WI/1/2013.

[13] Wijermans N., Understanding crowd behaviour: simulating situated individuals, University of Groningen, 2011, [dok. elektr.], irs.ub.rug.nl/dbi/4da43b2914b09, [dostęp 09.2015]..

[14] Sime J.D., Crowd psychology and engineering, „Safety Science", Vol. 21 Issue 1, 1995, pp. 1-14.

[15] Groner N.E., International systems representations are useful alternatives to physical systems representations of fire-related human behavior, „Safety Science”, Vol. 38, 2001, pp. 85-94.

[16] Couch C.J., Collective Behavior: An Examination of Some Stereotypes, „Social Problems”, Vol. 15 Issue 3, 1968, pp. 310-322.

[17] Waddington D.P., Jones K., Critcher C., Flashpoints: Studies in Public Discorder, Routledge 1989.

[18] Turner J.C., Reynolds K.J., The story of social identity, [w:] Rediscovering Social Identity, T. Postmes, N. Branscombe (red.), Psychology Press, 2010, pp. 13-32.

[19] Novikova K., Społeczne teorie tożsamości: Przegląd wybranych koncepcji, „Journal of Modern Science”, Vol. 17 Issue 2, 2013, pp. 377-395, [dok. elektr.] http://www. academia.edu/7056671/Spo\%C5\%82eczne_teorie_ to $\%$ C5\%BCsamo\%C5\%9Bci_przegl\%C4\%85d_wybranych_koncepcji_Kateryna_Novikova, [dostęp 09.2015].

[20] Drury J.R., Reicher S., Collective action and psychological change: The emergence of new social indentities, „British Journal of Social Psychology”, Vol. 39, 2000, pp. 579-604, [dok. elektr.], http://onlinelibrary.wiley.com/ doi/10.1348/014466600164642/pdf, [dostęp 09.2015].

[21] Adang O.M.J., Preventing Crowd Violence, chap. Initiation and escalation of collective violence: a comparative observational study of protest and footballevents, Criminal Justice Press, In press, 2010. 
[22] Valk P. van der, Linckens P., Voetbalvandalen: hun contacten met politie en Justitie, „Tijdschrift voor Criminologie”, Issue 4, 1988, pp. 313-320.

[23] Harrington J., Soccer Hooliganism, John Wright, Bristol 1968.

[24] Brug, H. van den, Voetbalvandalisme, een speurtocht naar verklarende factoren. De Vrieseborch, Haarlem [1986].

[25] Schreckenberg, M., Sharma, S., Pedestrian and Evacuation Dynamics, Springer Verlag, Berlin 2002.

[26] Helbing D., A fluid-dynamic model for the movement of pedestrians, "Complex Systems" Issue 6, 1992, pp. 391-415.

[27] Okazaki, S., A study of pedestrian movement in architectural space, part 1: Pedestrian movement by the application on of magnetic models, Trans. of A.I.J. 283, 1979, 111-119.

[28] Ali S., Shah M., Floor fields for tracking in high density crowd scenes. Computer Vision Lab, University of Central Florida, Orlando, USA, In Proc. ECCV., 2008 [dok. elektr.] http:// vision.eecs.ucf.edu/projects/sali/CrowdTracking/2008_ ECCV_TrackingInCrowds.pdf, [dostęp 09.2015].

[29] Hughes R., The flow of human crowds, „Annual Review of Fluid Mechanics", Vol. 35, 2003, pp. 169-182 [dok. elektr.] http://www.cs.uu.nl/docs/vakken/mpap/papers/15.pdf , [dostęp 09.2015].

[30] Treuille A., Cooper S., Popovic Z., Continuum crowds, „Journal Transactions on Graphics", Vol. 25, 2006, pp. 1160-1168 [dok. elektr.] http://grail.cs.washington.edu/projects/crowdflows/continuum-crowds.pdf, [dostęp 09.2015].

[31] Bonabeau E., Agent_based modeling: Methods and techniques for simulating human systems. „Proc. National Academy of Sciences of the United States of America", Vol. 99, 2002, pp. 7280-7287. [dok. elektr.] http://www.pnas.org/content/99/suppl_3/7280.full, [dostęp 09.2015].

[32] Helbing D., Dirk, Molnár P., Social force model for pedestrian dynamics, „Physical Review E”, Vol. 51, 1995, pp. 4282-4286.

[33] Helbing D., Farkas I., Vicsek T., Simulating dynamical features of escape panic, „Nature”, Vol. 407, 2000, pp. 487-490 [dok. elektr.] http://angel.elte.hu/panic/, [dostęp 09.2015].

[34] Vicsek T., Czirok A., Ben-Jacob E., Cohen I., Shochet O., Novel type of phase transition in a system of self-driven particles, "Physical review letters", Vol. 75, 1995, pp. 12261229 [dok. elektr.] http://www.seas.upenn.edu/ jadbabai/ ESE680/Vicsek_SPP.pdf, [dostęp 09.2015].

[35] Couzin I.D., Krause J., James R., Ruxton G.D., Franks N.R., Collective memory and spatial sorting in animal groups, „J. theor. Biol.", Vol. 218, 2002, pp. 1-11 [dok. elektr.] http:// www.princeton.edu/ icouzin/Couzin\%20et\%20al\%20JTB. pdf, [dostęp 09.2015].
[36] Park J., Collective motion in 3D and hysteresis, 2011 [dok. elektr.] http://uu.diva- portal.org/smash/get/diva2:431571/ FULLTEXT01.pdf, [dostęp 09.2015].

[37] Homepage of ETH Zurich's Chair of Sociology, in particular of Modeling and Simulation (SOMS) [dok. elektr.] http:// www.soms.ethz.ch/ [dostęp 09.2015].

[38] Helbing D., Molnár P., Farkas I., Bolay K., Self-organizing pedestrian movement, „Environment and Planning B: Planning and Design", Vol. 28, 2001, pp. 361-283.

[39] Kułakowski K., Automaty komórkowe, AGH-UST, Ośrodek Edukacji Niestacjonarnej, 2000.

[40] Wąs J., Algorytmy modelownia inteligentnych zachowań $w$ zagadnieniach dynamiki pieszych $z$ zastosowaniem niehomogenicznych automatów komórkowych, rozprawa doktorska, AGH, Kraków, 2006, [dok. elektr.] http://winntbg.bg.agh. edu.pl/rozprawy/9768/full9768.pdf, [dostęp 09.2015].

[41] Dudek-Dyduch E., Wąs J., Knowlege Representation of Pedestrian Dynamics in Crowd: Formalism od Cellular Automata, ICAIS Lecture Notes in Computer Science, Springer-Verlag, 4029, 2006, 1101-1110.

[42] Nowak P., Systemy agentowe, AGH [dok. elektr.] watchman. googlecode.com/files/Agents\%20system\%20-\%20article. pdf, [dostęp 09.2015].

[43] Bandini S., Manzoni S., Vizzari G., Situated Cellular Agents: a Model to Simulate Crowding Dynamics, IEICE Trans., E85-A, 2002, [dok. elektr.] http://www.researchgate.net/ publication/220238705_Situated_Cellular_Agents_A_Model_to_Simulate_Crowding_Dynamics, [dostęp 09.2015].

[44] Bandini S., Federici M.L., Giuseppe Vizzari G., Situated Cellular Agents Approach to Crowd Modeling and Simulation, „Cybernetics and Systems”, Issue 8, 2007, pp. 729-753, [dok. elektr.] http://www.researchgate.net/ publication/220231376_Situated_Cellular_Agents_Approach_to_Crowd_Modeling_and_Simulation, [dostęp 09.2015].

[45] Wąs J., Lubaś R., Towards realistic and effective Agent-based models of crowd dynamics, „Neurocomputing”, Vol. 146, 2014, pp. 199-209 [dok. elektr.] http://www.researchgate. net/publication/265359722_Towards_realistic_and_effective_Agent-based_models_of_crowd_dynamics, [dostęp 09.2015].

[46] Barański M., Maciak T., Określanie czasu procesu bezpiecznej ewakuacji ludności z zagrożonych obiektów, „Zeszyty Naukowe SGSP", 49 (2014), 78-97.

[47] Barański M., Maciak T.; Możliwości wspótczesnego oprogramowania do symulacji procesu ewakuacji ludności z zagrożonych obiektów, „Zeszyty Naukowe SGSP”, 50 (2014), 5-25.

dr hab. inż. Tadeusz Maciak - profesor Politechniki Białostockiej, zatrudniony w Katedrze Mediów Cyfrowych i Grafiki Komputerowej Wydziału Informatyki Politechniki Białostockiej, profesor Szkoły Głównej Służby Pożarniczej w Warszawie, kierownik Zakładu Informatyki i Łączności w SGSP. Autor wielu publikacji związanych ogólnie z problematyką szeroko pojętej obronności wewnętrznej kraju.

mł. kpt. mgr inż. Mariusz Barański - absolwent Szkoły Głównej Służby Pożarniczej (Wydział Inżynierii Bezpieczeństwa Pożarowego) oraz Politechniki Wrocławskiej (Informatyka na Wydziale Elektroniki). Od 2005 r. zatrudniony w Komendzie Powiatowej Państwowej Straży Pożarnej w Oławie. W służbie wielokrotnie prowadził działania ratowniczo-gaśnicze w sytuacjach zagrożenia, obecnie kieruje działaniami ratowniczo-gaśniczymi na poziomie interwencyjnym (dowódca zmiany). Autor publikacji z zakresu ewakuacji. 